Patty A. Gray, Nikolai Vakhtin and Peter Schweitzer. 2003. “Who owns Siberian ethnography? A critical assessment of a re-internationalized field." Sibirica, Vol. 3, No. 2, pp. 194-216.

WHO O W N S I B E I A N E TH NOGRAPH Y?

A Critical Assessment of a Re-Internationalized Field

\author{
Patty Gray \\ University of Alaska Fairbanks \\ tel. +1-907-474-6188 \\ fax +1-907-474-7453 \\ ffpag@uaf.edu \\ Nikolai Vakhtin \\ European University at St. Petersburg \\ tel. +7-812-275-5257 \\ nik@eu.spb.ru \\ Peter Schweitzer \\ University of Alaska Fairbanks \\ tel. +1-907-474-5015 \\ fax +1-907-474-7453 \\ ffpps@uaf.edu
}




\section{Who owns Siberian ethnography? A critical assessment of a re-internationalized field}

\section{Abstract}

Although Siberian ethnography was an open and international field at the turn of the 20th century, from about 1930 until the late 1980s Siberia was for the most part closed to foreigners and therefore to Western ethnographers. This allowed Soviet ethnographers to establish a virtual monopoly on Siberian field sites. Soviet and Western anthropology developed during that period in relative isolation from one another, allowing methodologies and theoretical approaches to diverge. During glasnost' and after the collapse of the Soviet Union, the Siberian field was reopened and field studies were conducted by several Western ethnographers. The resulting encounter between Western and former Soviet ethnographers in the 1980s and 1990s produced a degree of cultural shock as well new challenges and opportunities on both sides. This is an experiential account of the mood of these newly reunited colleagues at the turn of the $21^{\text {st }}$ century.

Keywords: Siberia, Jesup, Soviet and Russian ethnography, social and cultural anthropology, fieldwork, anthropological theory and method, ethics

\section{Introduction $^{1}$}

To ask 'who owns Siberian² ethnography' may seem absurd - how can an entire scientific area 'belong' to anyone? Yet, with the transformation in the discipline that occurred following the collapse of the Soviet Union in 1991, there came a moment of reflection a decade afterwards that made the question seem worth asking, even if only rhetorically. It is indeed a provocative question, meant to invite an airing among colleagues of long submerged views about that transformation. In March 2002, a group of Siberianist ethnographers and graduate students - half from Russia and eastern Europe, half from western Europe and North America ${ }^{3}$ - came together for a face-to-face meeting, not to present papers on the topic of Siberian ethnography, but to debate precisely this question and the issues surrounding it. This article is in part an airing of the views that emerged from that unique encounter. 
The decade of the 1990s was exciting for all ethnographers of Siberia, regardless of their country of origin. There was a small explosion of field studies in Siberia, as well as a proliferation of publications based on this fresh, cutting-edge material. Yet the quality of individual ethnographers' experiences - whether it was predominantly positive, or tinged with bitter irony - was often influenced by one's country of origin. Much of the new field research was not being conducted by Russian ethnographers, but by scholars from Europe, Japan, and North America, many of whom were neophytes having their first field experience. Meanwhile, many veterans of Siberian ethnography in Russia were unable to obtain adequate funding for their own fieldtrips (and sometimes even to put food on their own table). As Russian (Soviet) ethnography was struggling with a compulsion to turn figuratively Westward to engage in a newly opened arena of theoretical debate (Tishkov 1992), Western ethnographers were literally turning eastward ${ }^{4}$ to take advantage of a newly opened field site.

The irony could not go unnoticed by either side. The current article is one reflection on this period and its outcomes, co-authored by active field ethnographers from different sides of this experience (one Russian, one Austrian, one North American), attempting to bring their perspectives together in a dialogue. In that respect, it is primarily an experiential account, and does not purport to represent the whole range of experiences that might be expressed (either by those at the March 2002 meeting or by other ethnographers who have been working in Siberia). This dialogue is occurring in a period of openness - not unprecedented, as this article will show - but there is no guarantee that the current openness will continue unabated (in fact, there are already signs to the contrary). What can be permanent, however, is the consciousness among Siberian 
ethnographers that they constitute among themselves a scholarly community, and their own personal networks are to a great extent what maintains the international character of their field.

The ethnography of Siberia began unequivocally as an international field of endeavour. Its foundations were laid by the work of the Jesup North Pacific Expedition of 1897-1902, which sponsored the work of 16 field researchers to gather data on the Arctic and Subarctic cultures of far eastern Siberia and the coast of far western North America, in order to better delineate the connections between them (Freed et al. 1988; Kendall and Krupnik 2003). Russian ethnographers naturally played a significant role in this emerging international field. In turn, Siberian ethnography came to play a significant, if not central role in Russian (and later Soviet) ethnography generally, primarily through the influence of Vladimir Bogoraz, Waldemar Jochelson, and Lev Shternberg (the former two being key figures in the Jesup work, the latter being introduced by them into the 'Jesup network', as Igor Krupnik phrases it) (Krupnik 1998). These three met with the key figure in the Jesup work from the American side, Franz Boas, at conferences in Europe and the United States throughout the 1920s, and other scholars began to plan field expeditions to Siberia during that time (Krupnik 1998:203, 206). These contacts helped foster the open and international character of Russian/Soviet ethnography in the early decades of the twentieth century.

However, Stalin's rise to power in the 1920s and subsequent shifts in Soviet policy simultaneously began to create an atmosphere of hostility toward any activities or ideas perceived to be anti-Marxist, or even simply not Marxist enough. Jochelson emigrated to the United States in 1922, leaving Bogoraz and Shternberg to reign, 
however briefly, as the leaders of Soviet ethnography, but they soon fell into the 'notMarxist-enough' category by virtue of their populist views (Slezkine 1991). The pressure on them became apparent as they began to pull back from their international contacts, and by 1930, Siberia became closed to Western field researchers (it should be noted that the 1917 Russian Revolution does not mark the start of the period of closure) (Krupnik 1998:208). For the rest of the Soviet period, the ethnography of the peoples of Russia (the USSR) was almost exclusively the province of Russian (Soviet) ethnographers.

\section{A closed and 'tranquil' field}

Since the Soviet border was almost impermeable from the inside as well as the outside, it meant that Soviet ethnographers had difficulty accessing field sites outside the Soviet Union (Tishkov 1992:375). ${ }^{5}$ This made Siberia - an 'exotic' field site right at home - a logical career choice for many ethnographers (the Caucasus region and Central Asia were other favoured options). In the intervening years, from the closing of the field to foreigners in 1930 to its reopening in the late 1980s, Soviet ethnographers working alone in the guarded 'tranquillity' of their Siberian field produced a prodigious amount of work, which became quite important to the development of theory and method in Soviet ethnography. Leningrad led the way after the Russian Revolution, building on a legacy of Siberian scholarship established in the $18^{\text {th }}$ century (Schweitzer 2000). The heart of the so-called 'Leningrad School of Ethnography' was the Faculty of Ethnography at the Geographical Institute, where Shternberg and Bogoraz taught the first generation of Soviet anthropologists, many of whom took up work in Siberia and other parts of the North (Gagen-Torn 1971; Ratner-Shternberg 1935). The hallmark of the Leningrad 
School was its emphasis on long-term fieldwork, and the practical elements of its curriculum suited the needs of the young state for applied anthropology in the North. The school graduated such outstanding scholars of Siberian ethnography as Erukhim Kreinovich, Andrei Popov, and Georgii Prokof'ev.

After World War II, Moscow emerged as the new centre of Soviet ethnography and gradually also became a leading centre of Siberian research when the Institute of Ethnography of the Academy of Sciences of the USSR was moved from the Neva River to the Moscow River. An informal group of enthusiasts for the North evolved within the institute, and in 1954 received official standing with the name 'Department for the Study of the Socialist Build-up among the Peoples of the North.' The driving force within the department was Boris Dolgikh, who made outstanding contributions to the fields of ethnohistory and historical demography of Siberia (e.g., Dolgikh 1960). His successor, Il'ia Gurvich, continued Dolgikh’s legacy of historically oriented investigations of ethnic processes until the collapse of the Soviet Union. ${ }^{6}$ Meanwhile, at Moscow State University, Sergei Tokarev established a school of ethnography, and from the 1960s to the 1980s taught courses on the theory and methodology of foreign ethnography. Many of the students he trained went on to become Siberianists.

However, despite the gains made by Moscow in the field of Siberian studies after World War II, Leningrad remained the centre of Siberian studies throughout Soviet times. Unlike Moscow, the city on the Neva has the advantage of housing the two main ethnographic museums of the country (the Museum of Anthropology and Ethnography of the Academy of Sciences, a.k.a. the Kunstkamera, and the State Museum of Ethnography of the Peoples of the USSR), which are filled with Siberian artefacts. The Kunstkamera 
also housed the Leningrad branch of the Academy's Institute of Ethnography (as it does today). Its Department of the North was chaired by Leonid Potapov, a specialist of the Turkic-speaking peoples of southern Siberia. In addition to Potapov and the aforementioned Andrei Popov, an impressive list of Siberian scholars worked there in the postwar years. ${ }^{7}$ However, Siberian ethnography in Leningrad was not limited to these institutions. Given the Sternberg-Bogoraz legacy of combining linguistic and ethnographic training, the Institute of Linguistics of the Academy of Sciences in Leningrad housed pre-eminent linguist-ethnographers of the North, such as the aforementioned Erukhim Kreinovich.

Aside from these two 'capitals', scholarly centres of Siberian ethnographic research had been developing within Siberia itself since the second half of the $19^{\text {th }}$ century, primarily in Irkutsk, Tomsk, and Omsk. Many of these regional centres saw their most productive period during the 1920s, when the struggling political and academic capital was not strong enough to inhibit their scholarly creativity. The only institution inside Siberia that managed to compete with both Leningrad and Moscow over the long term was the Institute of History, Philology, and Philosophy of the Siberian Branch of the Academy of Sciences of the USSR in Novosibirsk, established in the 1960s by Aleksei Okladnikov - the 'founding father' of Siberian archaeology. Although primarily known as a centre for archaeology, the institute was also an important site for ethnographic research. The work of Izmail Gemuev and his colleagues there resulted in excellent descriptions of traditional worldview systems in western and southern Siberia, a kind of Soviet version of symbolic anthropology. 
Soviet ethnography's theoretical orientation during the early post-war years was largely defined by the issue of 'ethnogenesis', the reconstruction of the origin and early history of particular ethnic groups. Other key concepts were signified by the terms 'economic-cultural type' and 'historical-ethnographic province' (Levin and Cheboksarov 1955), which demonstrated a strange combination of diffusionism and Marxism. Later, in the 1960s, the new director of the Institute of Ethnography, Iulian Bromlei, developed the so-called 'etnos theory' (e.g., Bromlei 1973), which put further emphasis on the supposed stability of cultural features while highlighting the impact of socioeconomic formations. ${ }^{8}$ This conceptual vehicle defined most of the more theoretically inclined contributions to Siberian studies in the 1970s and 1980s, especially in the emerging field of 'ethnosociology', which focused on changing family structures, the social mobility of ethnic groups, the frequency of inter-ethnic marriages, etc. (and which often assumed the emergence of a 'Soviet etnos' as a result of those processes). Despite all the emphasis on 'ethnogenesis' and 'ethnic processes', the issue of 'ethnic conflict' was - for obvious political reasons - almost entirely absent from the field of Soviet (and Siberian) ethnography.

\section{Enter 'The Foreigners'}

Although in the 1930s the claustrophobic closure of the field to foreigners had marked a radical change of direction, by the 1980s the almost complete absence of foreign researchers in Siberia (many parts of which had become 'closed' regions that even Soviet citizens had to have permission to enter) was taken entirely for granted. Finnish and Hungarian anthropologists, who had played a major role in early Siberian ethnography 
between the 1840s and the Russian Revolution (Schweitzer 2001: 122ff), had difficulties in getting access to Siberia after Word War II. For Hungarians, who were considered 'socialist brethren', the situation was slightly different but certainly far from easy. The most prominent Hungarian anthropologist of these days working in Siberia was Vilmos Diószegi. From the West, two notable exceptions to this field access 'blockade’ were Caroline Humphrey, a British anthropologist who visited Buriatiia for two months in 1967 as an exchange student at Moscow State University (Humphrey 1998:17) and Marjorie Mandelstam Balzer, an American anthropologist who joined a Leningrad University summer ethnographic ‘expedition’ to Khanty territory in 1976 (Balzer 1999:8). Their relatively brief field trips were arranged through official channels, and they were closely supervised (although each managed to get at least some time free to talk to local people without a supervisor present). ${ }^{9}$

Then, starting in the late 1980s and increasing in the early 1990s, these faint ripples on the smooth surface of social anthropological research in Siberia multiplied, disturbing the accustomed tranquillity of this landscape as more ethnographers began to appear from abroad. Many of these 'foreigners' were young people, graduate students of anthropology, intrigued by the unexpected new opportunities for gaining access to field sites that heretofore could only be explored in the imagination. Some of them came well funded, especially towards mid-decade as funding agencies supported new programs for post-Soviet research. Even without generous grants, their foreign currency stretched very far at a time when the ruble was undergoing extreme deflation. Meanwhile, by the early 1990s, funding for Russian field research, which had been generous in the past, had all but disappeared (in fact, funding of all kinds was cut or severely curtailed, meaning 
publications could not be issued, and library collections became drastically out of date). In accordance with the traditions of British social and North American cultural anthropology, these Western researchers came to Siberia for long periods of time, for a year or sometimes longer, and they moved around in their field sites unescorted and for the most part unrestricted. They established friendships there, settled in northern towns and villages with local families, migrated with reindeer herders, and in general behaved themselves - in the eyes of a few astonished authorities - entirely inexcusably, violating all the unwritten rules of conduct of Soviet times. ${ }^{10}$

By the end of the 1990s, anthropological fieldwork in Siberia had seemingly become a fashion in the West, and especially in the United States. All of the regions of Siberia, from Taimyr to Chukotka, Buriatiia to Sakhalin, were visited by more than a dozen Western researchers, some of whom were receiving their university educations in social and cultural anthropology in North America and Europe. ${ }^{11}$ Toward the end of the 1990s, the activities of these researchers began to bear their first fruits. Publications began to appear, from dissertations to articles to monographs and edited volumes; ${ }^{12}$ their authors became regular participants in Siberian studies conferences both in Russia and abroad.

From the perspective of the youngest foreign researchers, Siberian ethnography was an underrepresented field in their discipline. For many, any knowledge of the Russian and Soviet ethnographic tradition would have had to come primarily from their own inquisitiveness, for their anthropological training would have emphasized British, American and French traditions, perhaps even the German tradition in some cases, but likely made little if any mention that ethnography even existed behind the 'iron 
curtain. ${ }^{13}$ There were few elder Siberianists to pass on a legacy to students, ${ }^{14}$ and many students, while obtaining their disciplinary training from advisors in their home institutions, cultivated relationships with informal ‘advisors’ among émigrés such as Igor Krupnik and Boris Chichlo, or those such as Nikolai Vakhtin, Natalia Novikova, and Anna Sirina who, while based in Russia, actively sought contacts abroad. Some had long dreamed of going to Siberian field sites, had even made attempts in the 1980s, but were rebuffed by the tenacity of late Soviet bureaucrats. All of them had invested years of preparation time, studying Russian history and culture in general as well as the specific histories and cultures of Siberian peoples, and studying the Russian language at such a level that they were able not only to read the Russian-language sources, but to use the language in the field. Most of them initially sought out the Russian specialists in their chosen Siberian field, usually in Moscow or St. Petersburg, and gratefully received their advice and assistance (even if they chafed at what they may have perceived as gatekeeping by these elder scholars). Some had to overcome in themselves whatever latent (and antisocial) feelings of superiority they might harbour towards their Russian colleagues as a result of the vast differences in their theoretical interests and their methodology, in order to find respect for the work of those who had long since gone before them.

From the perspective of Russian researchers of Siberia, engaged in life-long research on the ethnography and languages of Siberia within a rather intimate cohort, the appearances of these eager foreigners brought about a transformation in the scientific 'landscape' of Siberian ethnography. This was manifested in a few different ways. First of all, it meant that the scientific community of Siberian studies researchers markedly 
increased in size, and moreover, grew younger overall. Added to about two dozen Russian Siberian specialists was a comparably-sized cohort of foreign colleagues. Alongside this increase went a process of gradual decrease in the number of Russian Siberia specialists, which happened in a number of ways: from natural causes; from the emigration of some established Russian scholars; and from the unwillingness of young scholars to take up work in a poorly paid (and in the mid-1990s often entirely unpaid) field. Against this background of thinning and aging ranks of colleagues at key institutions in Russia, the entrance of a dozen or so energetic young Western researchers to the field was very noticeable. Besides this, the themes of the ethnographic research of Western anthropologists were unusual and new for Russian scholars. In contrast to Russian (Soviet) ethnographers, whose main themes were connected with the past and 'traditional' forms of culture, the study of disappearing material and spiritual culture, ethnogenesis and ethnic history, Western anthropologists were concerned almost exclusively with contemporary phenomena: contemporary problems of reindeer herding, contemporary social change, contemporary ethnic identity and national conflict, questions of power and gender relations in contemporary communities of indigenous inhabitants. The appearance of these themes, and the corresponding publications and scientific conferences that explored them, were also part of the essential transformation in the 'landscape' of Siberian research. ${ }^{15}$

Yet another innovation consisted in the fact that the appearance of 'foreigners' in Siberia began to alter a relationship between ethnographers and those whom they studied that had remained unchanged for decades. For example, Tishkov (1998:4) relates an anecdote about one senior Siberian scholar who encountered a negative change in her 
informants' attitude toward her after a 'jump-in-jump-out’ visit by North American visual anthropologists who had left behind video equipment for the use of the local community. Such anecdotes reveal the sense of disruption felt by Soviet Siberianists. In some sense, one can say that in the Soviet period Siberia was ‘divided up’ between researchers from Moscow, Leningrad, Novosibirsk, Tomsk, Yakutsk and a few other cities. There was an unspoken convention of securing for each researcher his or her own region, language or ethnic group. In purely logistical terms it might be argued that, since there were only a few researchers and the territory to be studied was enormous, ethnographers had to distribute themselves widely if all of Siberia was to be represented in science. ${ }^{16}$ But to some extent this division of labour was consciously reinforced, for reasons that were perhaps more careerist than scientific. Intentional or unintentional violators of the convention were sometimes 'put in their place' rather strictly and warned about the potential consequences of encroaching 'in someone else's garden.' Yet in the 1990s, alongside almost every Russian ethnographer, one Western colleague (or competitor, depending on one's point of view) appeared as a kind of shadow, working in the very same regions, in the very same towns, often simultaneously (two of the authors found themselves in this very situation in Chukotka in 1996). If there had ever been any idea of a 'natural monopoly' of Russian scholars to their 'own' people, region or language, this came to an end.

And, finally, with the appearance in Siberia of foreign scholars, the theoretical uniformity of Soviet (Russian) ethnography was encroached upon by a dizzying theoretical plurality. In the Soviet period, the theory of etnos was (like it or not) 'unanimously' endorsed, and all worked, whether out of fear or out of conscience, within 
the limits of this model or at a minimum within its terminology, making their obligatory citations of Marx, Lenin, and Brezhnev. The possibility of choosing one's theory and methodology, the possibility of using a variety of conceptual and terminological systems for describing ethnographic and social-anthropological facts, was for Russian (Soviet) ethnographers something new. It was not as if all 'foreign' theoretical or methodological approaches were necessarily good, or that foreign colleagues did not have their own methodological stereotypes or fashionable theories - obligatory citations of Bakhtin and Jakubinsky, Michel Foucault and Roland Barthes, Ernest Gellner and Benedict Anderson could be found in their work. However, the very fact that these were different theories, and that it was possible to choose between a variety of approaches, exerted a noticeable effect on Russian researchers.

All of these changes, coming all at once, could not help but produce a bit of emotional shock in Siberian ethnographers on all sides of the equation. While some young Western scholars may have struggled to understand Russian theoretical and methodological approaches and perceived Russian elder gate-keeping, the elder Russian scholars may have perceived audacity on the part of these latecomer Siberianists who seemed to presume that they could instantly claim a rightful place in field sites that senior scholars had spent a lifetime cultivating. It was difficult not to harbour at least some resentment when Westerners came well funded, while some ethnographers in Russia were quite literally going hungry in their home institutions and could only dream of when their next field trip might be (Vainshtein 1998:12). Some had to overcome a sense of shame in order to accept financial support from foreign foundations and reconcile themselves to the position of co-investigator on the grants of foreign colleagues. Others 
(especially those outside St. Petersburg and Moscow) took advantage of opportunities to gain financial support by providing local assistance for field projects in Siberia. For all, it was exhilarating to attend conferences abroad and interact with a wider sphere of scholars, but then again there was another kind of shock at seeing how well appointed their colleagues' institutions were, making their own home institutions seem shabby by comparison.

These changes in the landscape of Siberian studies became especially noticeable at the end of the 1990s, when the first cohort of Western graduate students had successfully defended their Ph.D. dissertations, started publishing books and articles, and began gradually to occupy more and more notable positions in the international social anthropological network. And although the idea of 'studying Siberia' no longer summons forth such agiotage among Western students as it did a decade ago, nevertheless it is obvious that this period of change was not merely a fluke: Siberian ethnography has irreversibly become an international sphere of knowledge, and it is clear that this reinternationalisation will only be strengthened in the future.

\section{So who owns it, then?}

It was against this background that a few members of the now international community of Siberian ethnographers, who had themselves witnessed and participated in these changes, were inspired to come up with the idea of organizing a workshop, to gather together Russian and Western ethnographers of Siberia and try to answer a single question. The question was not really ‘who owns Siberian ethnography’ but rather 'Where do we stand?' The emotional shock of those initial encounters in the 1990s had 
passed by this time, and scholars from both sides of the former divide were able to take a more detached view of the issues at hand, looking toward the future. Nineteen Siberian specialists participated in the workshop, half of them from Russia and half from Europe and North America, and many of them brought two or three of their own graduate students. The participants were asked (to the perplexity of many) not to prepare formal papers, but instead each was assigned a broad topic, and asked to make a brief presentation outlining what s/he saw as the key issues surrounding that topic. It was emphasized that the presentations should be informal, should rely upon the personal experience of the presenter, and should not shy away from being provocative (see Appendix I). In the intimacy and informality of this gathering, participants felt comfortable stating - in some cases with considerable humour - the lingering resentments and disappointments of their experiences in the 1990s. A distinctive collage of thoughts, ideas, and opinions developed over the three days of intensive discussions, but three areas of concern emerged as central: 1) the object of research; 2) the theories and methods of research; and 3) the ethical aspects of field work. The remainder of this paper seeks to capture some of the views raised at the workshop regarding these concerns. Far from seeking to exhaust these issues, the goal is to share what was a limited conversation with a wider community of scholars, with the hope of inspiring further reflection on the past of Siberian ethnography and discussion of its future development.

\section{The Object of Research}

Territory or 'people.' In Russia, ethnographic methods and the very program of ethnographic inquiry were established for the purpose of describing territories and the 
local groups found within them. However, in Soviet ethnography these methods and approaches were applied to etnosy or ethnic groups, which created a problem when trying to describe peoples that were either distributed across a large territory (such as Evens, Evenkis, and Nentsy) or situated in close contact with others (such as Yukagirs, Nanais, and Selkups). The result has been a tendency to artificially circumscribe groups spatially and ethnically, treating very different local communities as a single people while bracketing out complicating factors such as the mixing of communities. For Western anthropologists, the territorial approach to defining the object of study is more the custom - thus the object of study is just as likely to be Chukotka as the Chukchi (who may also be found in Magadan and Sakha), or a village with an ethnically mixed population. Many Russian ethnographers find this to be a welcome lifeline out of the etnos box. However, workshop participants agreed that defining the object of study (whether as a territory or as a people) is not the end of the matter, for what is needed is not mere description, but analytical study of the practices of the people themselves.

Indigenous population or entire population. Following from the above, it is a rather more difficult matter for some Russian ethnographers to see non-indigenous peoples as being a potential object of study, since they previously took it for granted that their object of study as ethnographers was to be the indigenous population. This has been a bias in Western ethnography as well, and the fact that in most studies of Siberia to date the non-indigenous population appears peripherally, if at all, is evidence that the bias has not been completely shaken. Clearly, contemporary Siberia is a complex field, and cannot be boiled down to a simple dichotomy between indigenous and non-indigenous ('incomer') populations (as was most convincingly argued by the students at the 
workshop). In any given region of Siberia, there will be other social actors besides the indigenous population who are significant players in the social field and are bracketed out only at the risk of creating a distorted and idealized picture of the indigenous people of the area. Local authorities, local industrialists ('oilmen'), Russian Old Settlers, the permanent Russian population ('locals'), the temporary Russian population ('incomers'), all factor to varying degrees in the social constellation of Siberian communities. Whether these are studied in contrast to the indigenous populations, or in their own right, one and the same social anthropological method remains appropriate to all. Moreover, the same ethical principles for studying the indigenous population should also be applied to other categories of the population. This idea - that non-indigenous and even urban populations in Siberian cities should become the subject of social anthropological research to no less a degree than indigenous and rural populations - ran as a common thread through many of the discussions.

Balancing 'emic' and 'etic'. Western researchers, newly arriving in Siberia, experience difficulty in distinguishing two elements that are today a part of any 'northern' culture: that culture's own characteristics and those elements of it that are generally Russian (Soviet). For the Western researcher, all observable facts are taken as indications of the culture under study. By contrast, Russian ethnographers, owing to the fact that they grew up in and were moulded by Russian society, immediately recognize in northern cultures that general Russian element (that is, elements of Russian/Soviet culture that were introduced into the cultures of indigenous peoples), and they dismiss it as nonessential. In both cases, something is being lost - neither manages to capture the dynamic process of change experienced by the northern peoples themselves. Constant and 
benevolent collaboration among Russian and Western anthropologists opens the eyes of each to what the other finds either significant or superfluous. Both perspectives seem necessary in order for all significant aspects of the lived experience of Siberians to be delineated.

Community. One important and sometimes problematic concept that Western anthropology brought into Siberian ethnography is community, a shorthand way of referring to a complex phenomenon. This concept is not only difficult to translate (the Russian is obshchina, which is not exactly equivalent to 'community'), but the very content of it also varies as, for example, between Siberia and the Canadian arctic. What is a community, and how does one know when a community has been located? Is a community an empirical object in space and time, or a construction, either of the researcher (who must define the limits of study somehow) or of other forces (such as state agencies and NGOs who need a defined object to fit the delimitations of a 'project'). As it turns out, many 'communities' in Siberia - 'obshchiny korennogo naseleniia' were created relatively recently and artificially (during the forced relocations of the 1960s, or even later, during the destruction of the state farms in the early 1990s). More recently, indigenous peoples are seeking to define themselves as self-contained obshchiny, in an effort to exert more local autonomy and achieve local self-government (Fondahl et al. 2001; Gray 2001; Sirina 1999). However, singling out 'communities of indigenous peoples' is a dubious and to some extent artificial exercise insofar as these communities have a mixed character in many parts of Siberia and include both the permanent Russian population as well as Russian Old Settlers (Vakhtin et al. 2004). 
Also at issue here is the concept of collaborating with communities, which has become very popular with funding agencies. But does one really collaborate with a community or with individuals in a community? Any community will contain diverse interests, making it difficult for a single researcher to claim s/he is collaborating with 'the' community. Care must be taken not to reify community in such a way that these diverse interests are obscured.

\section{Theory and Methodology}

Past vs. present. The research program of Soviet ethnography, received as a legacy reaching back practically to the Kamchatka Expeditions - handed down through the works of such 'ancestors' as S. Krashenennikov, A. F. Middendorf, G. F. Müller, and G. Steller - constituted the foundation of most ethnographic description and teaching all the way up to the early 1980s in all institutions of higher learning in the USSR. This program - and all the theoretical paradigms of Soviet ethnography that grew out of it presupposed a distinction between material culture and spiritual culture (treating them in that order), gave special attention to the problems of ethnogenesis, ethnic history, and cultural typologies, and maintained an orientation towards the study of ethnographic facts as facts of the past. Although in the Western tradition of social anthropology there is a place for some of these themes, the contemporary situation takes precedence. The study of ethnic identity seems to be one area of overlap between Russian and Western colleagues, and yet the approaches differ: Western ethnographers pay close attention to ethnic self-identification, while the idea of asking indigenous peoples what they think about their own identity initially strikes ethnographers in Russia as odd. But this is an 
area of research that is growing in Russian ethnography of Siberia (e.g., Krupnik and Vakhtin 2002; Shnirel'man 1996, 2003; Vakhtin et al. 2004).

There are a few reasons why Russian ethnographers have been reluctant to address the study of contemporary phenomena. The first is simply force of habit - they have no precedent for seeing scientific problems as not existing in a by-gone, 'museum' reality, and they lack training in methods of research that could lead them in alternative directions. But beyond this, there is a sense that addressing contemporary phenomena is tantamount to a transition from 'pure' science to 'applied' - a path down which some of them would prefer not to start (although the Russian/Soviet tradition contains strong elements of applied research, such as in the ethnography of Vladimir Bogoraz). Others criticize this as a kind of escapism, a deliberate avoidance of contemporary problems (which would lead them to important economic, social, or medical issues) by taking refuge in the innocently ethnographic. However, as the funding structure changes, so do research priorities. The availability of money from sources like the Soros Foundation and the MacArthur Foundation, earmarked for contemporary issues, pushes Russian research in this direction.

Marxism. The position of Marxism in Russian and Western ethnography presents a particularly interesting paradox. Soviet ethnography was active in developing Marxist political economy from the start, but this was bastardized by the 1930s into 'vulgar Marxism', an orthodox line to which one had to adhere, and which dictated obligatory citations of dogmatic texts. This hindered the further development of Marxist theory in Soviet ethnography. Conversely, Marxist political economy was steadily developed in the West in the twentieth century, experiencing a particular florescence in the 1960s, until 
today it underlies a significant portion of contemporary theory in Western social and cultural anthropology. Some Russian scholars are eager to engage in the current Marxist debates, while others have a hard time overcoming the foul aftertaste of 'vulgar Marxism’.

The Theoretical Relevance of Siberia. A few workshop participants lamented that Siberian material is sometimes treated as a kind of exotica within the discipline of anthropology, and not given credit for theoretical sophistication or looked to for comparative models. Siberian ethnography certainly lacks the 'critical mass' attained by other area specializations in anthropology that have had a greater impact on the development of anthropological theory. However, the work of Siberian ethnographers represents a wide variety of theoretical perspectives and research agendas, addressing issues in arctic ecology, post-socialism, post-colonialism, social change, power and the state, ethnic identity, gender, and economic processes, among others. The growing field of Siberian ethnography is now poised in a position to drive the theoretical and comparative agenda of contemporary ethnography, to the extent that its representatives have the will to do so.

\section{Ethical aspects of research}

Siberian code of ethics? At the seminar there was quite a stormy discussion about whether a special Russian code of ethics for the conduct of field research is needed and about the responsibility of anthropologists toward the people being studied. It is well known that such codes of ethics have been passed by national and international anthropological associations (such as the American Anthropological Association, the 
Association of Canadian Universities for Northern Studies, and the International Arctic Social Science Association). Analogous rules of conduct for researchers have been passed even within indigenous communities, as indigenous peoples seek to exert more control over who may come to research among them and what kinds of research questions are appropriate. Some felt that an analogous code of ethics should be drafted and passed in Russia as a precedent. Others pointed out the logistical that there is no common organisation for Siberian studies in Russia that could pass such a code. Regarding rules of conduct within indigenous communities, doubts were raised about who really stood in the subject position of such codes - was it an indigenous community, or a local elite speaking for the community? Again, this comes back to the question of how community is constructed, i.e. if a researcher must obtain permission to conduct a study in a community, who is going to speak for that community and grant the permission? Who can represent that community in all its diversity? While these epistemological issues have been discussed at length within Western ethnography, such debates are relatively fresh in Russian ethnography.

Engagement to what degree? Some social anthropologists, both Russian and Western, see one of their main tasks as being the 'voice' of the indigenous population in Siberia: they feel it is their obligation to put their expertise to the service of the populations they study so as to help them (primarily in the legal sense) in their fight for their own rights. Others see this as treading a fine line between advocacy and paternalism, and question whether anthropologists have the right to impose their view of the problems on the indigenous population (how can an outsider be the 'voice' of a community). For Western anthropologists working in Russia, the situation is complicated 
by the fact that they, on account of their status as 'foreigners', are sometimes seen as having no right to interfere in local politics in Siberia, and may tread on shaky ground if they begin to take sides in political, economic and social conflicts. A different sort of complication presents itself to those ethnographers of Siberia in Russia who are themselves indigenous, making them perhaps appear automatically to be advocates whether they intend to or not. ${ }^{17}$

Perhaps the most profound ethical question concerns the study of dysfunctionality - a very salient matter in Siberia, since the withdrawal of the Soviet state and its attendant subsidies has triggered social crisis in many regions. Some outside observers, both Russian and Western, initially hailed what they believed to be a healthy 'return to subsistence’ in Siberia, once Soviet state modernisation pressures were modulated. However, the ensuing subsistence lifestyle in Siberia is in most cases not voluntary, but rather the catastrophic result of collapsing infrastructure and its attendant isolation. Local communities have experienced extreme stress, and problems such as alcoholism, suicide, and domestic violence are symptoms of this (Pika 1993). Presenting the lived experience of Siberians today seems to necessitate touching on this dysfunctional aspect, yet it is a delicate issue of representation. Many other Arctic communities do not want these negative aspects to be made public, seeing it as a kind of bad press for their communities. Yet public discussion and analysis of these problems is crucial to understanding and ameliorating them.

\section{Looking Towards the Future}


One of the main achievements of the seminar was that almost all participants were able to bring with them junior scholars working or preparing to work in Siberia. These young scholars clearly had their own ideas about the scope and future directions of Siberian ethnography. After the closing of the conference, one of the Russian graduate students said with a shade of surprise, addressing a group of her older colleagues: 'Strange that your generation takes this situation - the openness of Siberia for foreigners, the wide scale of joint research, the necessity to study contemporary phenomena, the necessity to obtain grants from international foundations to guarantee one's own work as something new and unusual. For us it is perfectly normal: it could not be otherwise.' The graduate students present at the workshop were exceptional, among the most talented entering the field today. However, some of the senior researchers present who had seen graduate student grant proposals (or Russians who had seen the students themselves when they visited their institutions) noted that the Russian research tradition was neglected by them, and that there was too much reliance on translations and little use of original sources. It was agreed that a minimum requirement for entering the field must be fluency in the Russian language, and students must be directed to review the original Russian language sources at least as thoroughly as the material published in their own languages. By the same token, this implies that Russian-speaking graduate students must also be fluent enough in a foreign language to review non-Russian literature on Siberia.

\section{Conclusion}

One participant pointed out that, although the decade of the 1990s constituted a transnational moment in Siberian ethnography, it did not necessarily mark the beginning 
of a transnational research tradition (Schweitzer 2001). What are transnational are the personal networks cultivated by researchers across all national boundaries, and this is not unique to late twentieth century ethnography - it has been true in all centuries. Considering how far apart they were little more than a decade ago, in a very short time Russian and Western Siberianists have gone from not knowing each other very well to being very close to one another, and by this point they already need one another. This change has come through personal networks.

The 1990s was a period of unprecedented opening, a vigorous pendulum swing from the paranoid closure of the Soviet period. But there is no reason to assume that the openness will only increase from here on out - in fact there are already signs of drawing back and re-closure. However, given the 'Pandora’s box’ character of global communication, it would seem that these transnational personal networks will continue as long as participants wish to pursue them. A great deal of energy is being invested in reinforcing international ties, not only by cultivating personal contacts in the present, but also by Siberianists reminding one another - in some cases teaching one another - about their own common historical heritage. ${ }^{18}$ The message of these activities seems to provide the answer to the question posed in the title of this article - a resoundingly collective ' $W e$ do.' Or, as one workshop participant phrased it, Siberian ethnography does not belong to anyone - rather, we belong to it.

\section{Appendix I: Themes and Participants in the Workshop 'Who Owns Siberian}

\section{Ethnography?’}

\section{Day 1: Historical and Theoretical Perspectives}


Peter Schweitzer, University of Alaska Fairbanks and University of Vienna:

- Historical Overview of Siberian Research

Anna Sirina, Institute of Ethnography and Anthropology:

- Russian/Soviet theoretical approaches and Siberian research in the Soviet period

John Ziker, Boise State University (formerly Max Planck Institute):

- Theoretical Approaches in the United States

David Anderson, University of Aberdeen:

- British and Canadian Theoretical Approaches

Olga Murashko, Moscow State University:

- Review of post-Soviet changes in field research

\section{Working Group Themes:}

1. What theoretical approaches do we have in common and how can we build on them?

2. What are the areas of miscommunication and how can they be overcome?

3. What kinds of institutional structures have supported research, and how can international links between them be strengthened?

\section{Day 2: Research Approaches and Ethics}

Konstantin Klokov, St. Petersburg State University:

- Fieldwork Techniques

Natalia Novikova, Institute of Ethnography and Anthropology:

- Where is 'the field'? Multiple locations, multiple levels

David Koester, University of Alaska Fairbanks: 
- Collaborating with local communities

Tatiana Argounova-Low, Scott Polar Research Institute:

- Practical and ethnical issues in advocacy anthropology

Piers Vitebsky, Scott Polar Research Institute:

- Dealing with poverty and social dysfunctionality

Erich Kasten, Max Planck Institute for Social Anthropology:

- Sharing results with local communities and incorporating feedback

Nikolai Vakhtin, European University of St. Petersburg:

- Team research or lone ethnographer?

\section{Working Group Themes:}

1. What are they key ethical issues that need to be addressed in the future?

2. What are the barriers to/opportunities for collaboration with members of local communities

3. Which field techniques seem to be most successful and culturally sensitive? What techniques have been overlooked?

4. What is the purpose of our research, both in an immediate sense and in the long term?

\section{Day 3: Research Agendas}

Evgeniy Golovko, European University of St. Petersburg:

- International collaboration (plusses and minuses)

Alex King, University of Aberdeen (formerly Max Planck Institute):

- Research Topics and Local Agendas

Igor Krupnik, Smithsonian Institution: 
- The lure of the past: Anthropologists or historians?

Patty Gray, University of Alaska Fairbanks (formerly Max Planck Institute):

- Finding funding and dealing with foundation agendas

Tatiana Roon, Sakhalin Regional Museum:

- The role of museums in contemporary Siberian research

Yulian Konstantinov, New Bulgarian University:

- Research training inside and outside academia

Nikolai Ssorin-Chaikov, Cambridge University (formerly Max Planck Institute):

- Post-Colonial theory and Siberianists anthropology

\section{Working Group Themes:}

1. What strategies can we develop for making the results of our research available to multiple audiences?

2. What strategies can we develop for collaborating with one another in research and balancing access to resources?

3. What strategies can we develop for maintaining on-going contacts with one another across time and great distances, between field projects?

4. What strategies can we develop for attracting, training and supporting young scholars entering this field?

Student Working group: What do you think are the key issues for Siberian research in the future? In what directions would you like to see the field develop?

\section{Appendix II: Chronological list of ethnographic dissertations on Siberia completed at institutions outside of Russia ${ }^{19}$}

Schindler, Debra (University of Massachusetts, 1990) 
Schweitzer, Peter (University of Vienna, 1990)

Grant, Bruce (Rice University, 1993)

Kwon, Heonik (University of Cambridge, 1993)

Anderson, David (Cambridge University, 1995)

Bloch, Alexia (University of Pittsburgh, 1996)

Lazar, Katalin (Jyvaskylan Yliopisto [Finland], 1996)

Rethmann, Petra (McGill University, 1996)

Sommer, Frank (University of Freiburg/Breisgau, 1996)

Kerttula, Anna (University of Michigan, 1997)

Fridman, Eva Jane Neumann (Brown Univeristy, 1998)

Gray, Patty (University of Wisconsin-Madison, 1998)

Kang, Jeong Won (University of Munich, 1998)

Pessman, Dale (The University of Chicago, 1998)

Ssorin-Chaikov, Nikolai (Stanford University, 1998)

Ziker, John (University of California-Santa Barbara, 1998)

Espiritu, Aileen (University of Alberta, 1999)

King, Alexander (University of Virginia, 1999)

Tuisku, Tuula (University of Lapland, Rovaniemi, 1999)

Bucher, Gudrun (University of Frankfurt/Main, 2000)

Hancock, Nelson (Columbia University, 2000)

Argounova, Tatiana (University of Cambridge, 2001)

Jordan, Peter (University of Sheffield, 2001)

Crate, Susan (University of North Carolina at Chapel Hill, 2002) 
Halemba, Agnieszka (University of Cambridge, 2002)

Emma Wilson (University of Cambridge, 2002)

Habeck, Otto (University of Cambridge, 2003)

Metzo, Katherine (Indiana University, 2003)

Sántha, István (ELTE University, Budapest, 2003)

Vaté, Virginie (University of Paris X Nanterre, 2003)

Donahoe, Brian (Indiana University, 2004)

Stammler, Florian (Max Planck Institute for Social Anthropology, 2004)

Ventsel, Aimar (Max Planck Institute for Social Anthropology, 2004)

\section{References to published literature}

Anderson, David (2000) Identity and Ecology in Arctic Siberia: The Number One

Reindeer Brigade. Oxford: Oxford University Press.

Anderson, David, and Kazunobu Ikeya, eds. (2001) Parks, Property, and Power:

Managing Hunting Practice and Identity within State Policy Regimes. Osaka: National Museum of Ethnology.

Balzer, Marjorie Mandelstam (1995) Introduction: What's 'Native' About Non-Russian Anthropology? In Culture Incarnate: Native Anthropology from Russia. ed. M.M. Balzer. Armonk, NY: M.E. Sharpe, pp. 3-28.

— (1999) The Tenacity of Ethnicity: A Siberian Saga in Global Perspective. Princeton, N. J.: Princeton University Press.

Bloch, Alexia (2003) Red Ties and Residential Schools: Indigenous Siberians in a PostSoviet State. Philadelphia: University of Pennsylvania Press. 
Bromlei, Iu. V. (1973) Etnos i etnografiia. Moscow: Nauka.

Bucher, Gudrun (2002) ‘Von Beschreibung der Sitten und Gebräuche der Völker’. Die Instruktionen Gerhard Friedrich Müllers und ihre Bedeutung für die Geschichte der Ethnologie und der Geschichtswissenschaft. Stuttgart: Franz Steiner Verlag.

Dolgikh, Boris O. (1960) Rodovoi i plemennoi sostav narodov Sibiri v XVII v. Moscow: Izdatel'stvo Akademii Nauk SSSR.

Fondahl, Gail (1998) Gaining Ground? Evenkis, Land, and Reform in Southeastern Siberia. Boston, MA: Allyn and Bacon.

Fondahl, Gail, Olga Lazebnik, Greg Poelzer, and Vasily Robbek (2001) Native 'land claims', Russian style. The Canadian Geographer 45(4):545-561.

Freed, Stanley A., Ruth S. Freed, and Laila Williamson (1988) Capitalist Philanthropy and Russian Revolutionaries: The Jesup North Pacific Expedition (1897-1902). American Anthropologist 90(1):7-24.

Gagen-Torn, N. I. (1971) Leningradskaia etnograficheskaia shkola v dvadtsatye gody (u istokov sovetskoi etnografii). Sovetskaia etnografiia 2:134-145.

Golovnev, Andrei V., and Gail Osherenko (1999) Siberian Survival: The Nenets and Their Story. Ithaca: Cornell University Press.

Grant, Bruce (1995) In the Soviet House of Culture: A Century of Perestroikas. Princeton, NJ: Princeton University Press.

Gray, Patty A. (2001) The Obshchina in Chukotka: Land, Property and Local Autonomy. Max Planck Institute for Social Anthropology Working Papers. Halle (Saale), Germany. 
— (2004) The Predicament of Chukotka's Indigenous Movement: Post-Soviet Activism in the Russian Far North. New York: Cambridge University Press.

Humphrey, Caroline (1998) Marx Went Away but Karl Stayed Behind (Updated Edition of Karl Marx Collective: Economy, Society and Religion in a Siberian Collective Farm). Ann Arbor: The University of Michigan Press.

Jordan, Peter (2003) Material Culture and Sacred Landscape: The Anthropology of the Siberian Khanty. Walnut Creek, CA : AltaMira Press.

Kasten, Erich, ed. (2002) People and the Land: Pathways to Reform in Post-Soviet Siberia. Berlin: Dietrich Reimer Verlag.

- (2004) Properties of Culture, Culture as Property: Pathways to Reform in PostSoviet Siberia. Berlin: Dietrich Reimer Verlag.

Kendall, Laurel, and Igor Krupnik, eds. (2003) Constructing Cultures Then and Now: Celebrating Franz Boas and the Jesup North Pacific Expedition. Washington, DC: Arctic Studies Center, National Museum of Natural History, Smithsonian Institution.

Kerttula, Anna M. (2000) Antler on the Sea: The Yup'ik and Chukchi of the Russian Far East. Ithaca, NY: Cornell University Press.

Koester, David (2002) When the Fat Raven Sings: Mimesis and Environmental Alterity in Kamchatka's Environmentalist Age. In People and the Land: Pathways to Reform in Post-Soviet Siberia, ed. E. Kasten. Berlin: Dietrich Reimber Verlag. pp. 45-62.

Konstantinov, Yulian (2000) Pre-Soviet Pasts of Reindeer-Herding Collectivities :

Ethnographies of Transition in Murmansk Region. Acta Borealia 17(2):49-64.

Krupnik, Igor (1993) Arctic Adaptations: Native Whalers and Reindeer Herders of Northern Eurasia. Hanover, NH: University Press of New England. 
— (1998) Jesup Genealogy: Intellectual Partnership and Russian-American Cooperation in Arctic/North Pacific Anthropology. Part I: From the Jesup Expedition to the Cold War, 1897-1948. Arctic Anthropology 35(2):199-226.

Krupnik, Igor, and Nikolai Vakhtin (2002) In the 'House of Dismay': Knowledge, Culture, and Post-Soviet Politics in Chukotka, 1995-1996. In People and the Land: Pathways to Reform in post-Soviet Siberia, ed. E. Kasten. Berlin: Dietrich Reimer Verlag, pp. 7-43.

Levin, M. G., and N. N. Cheboksarov (1955) Khoziaistvenno-kul'turnye tipy i istorikoetnograficheskie oblasti. Sovetskaia etnografiia (4):3-17.

Limon, Jose E. (1991) Representation, Ethnicity and the Precursory Ethnography: Notes of a Native Anthropologist. In Recapturing Anthropology: Working in the Present, ed. R.G. Fox. Santa Fe, NM: School of American Research Press, pp. 115-135. Narayan, Kirin (1993) How Native is a "Native” Anthropologist? American Anthropologist 95(3):671-686.

Pika, Aleksandr (1993) The Spatial-Temporal Dynamic of Violent Death Among the Native Peoples of Northern Russia. Arctic Anthropology 30(2):61-76.

Pika, Aleksandr, ed. (1999) Neotraditionalism in the Russian North: Indigenous Peoples and the Legacy of Perestroika. Seattle: University of Washington Press. Ratner-Shternberg, S. A. (1935) L. Ia. Shternberg i Leningradskaia etnograficheskaia shkola 1904-1927 gg. Sovetskaia etnografiia 2:134-154.

Rethmann, Petra (2001) Tundra Passages: History and Gender in the Russian Far East. University Park: Pennsylvania State University Press.

Schindler, Debra (1997) Redefining Tradition and Renegotiating Ethnicity in Native 
Russia. Arctic Anthropology 34 (1):194-211.

Schweitzer, Peter P. (2000) The Social Anthropology of the Russian Far North. In: The Arctic: Environment, People, Policy. eds. M. Nuttall and T. V. Callaghan. Amsterdam, The Netherlands: Harwood Academic Publishers, pp. 411-439.

— (2001) Siberia and Anthropology: National Traditions and Transnational Moments in the History of Research. Post-doctoral thesis; Faculty of the Human and Social Sciences, University of Vienna.

Schweitzer, Peter P., and Evgeniy Golovko (1995) Travelling Between Continents: The Social Organization of Interethnic Contacts Across Bering Strait. Anthropology of East Europe Review 13(2):50-55.

Shimkin, Demitri B. (1990) Siberian Ethnography: Historical Sketch and Evaluation. Arctic Anthropology 27(1):36-51.

Shirokogorov, S. M. (1922) Etnos. Issledovanie osnovnykh printsipov izmeneniia etnicheskikh i etnografichesikh iavlenii. Vladivostok.

Skalník, Peter (1986)Towards an Understanding of Soviet etnos Theory. South African Journal of Anthropology 9:157-166.

Shnirel'man, V. A. (1996) Who gets the past? Competition for Ancestors among nonRussian Intellectuals in Russia. Washington: Woodrow Wilson Center Press. 1996.

— (2003) Voiny pamiati: Mify, identichnost' i politika v Zakavkaz'e. Moscow:

Akademkniga.

Sirina, A.A. (1999) Rodovye obshchiny malochislennykh narodov Severa v Respublike Sakha (Iakutiia): shag k samoopredeleniiu? Issledovaniia po prikladnoi i neotlozhnoi etnologii, Vol. 126. Moscow: Russian Academy of Sciences, Institute of Ethnology and 
Anthropology.

Slezkine, Yuri (1991) The Fall of Soviet Ethnography, 1928-38. Current Anthropology 32(4):476-484.

— (1994) Arctic Mirrors: Russia and the Small Peoples of the North. Ithaca, NY:

Cornell University Press.

Ssorin-Chaikov, Nikolai (2003) A Social Life of the State in Subarctic Siberia: Stanford, CA: Stanford University Press.

Takakura, Hiroki, ed. (2003) Indigenous Ecological Practices and Cultural Traditions in Yakutia: History, Ethnography, and Politics. Sendai: Center for Northeast Asia Studies, Tohoku University.

Tishkov, Valery A. (1992) The Crisis in Soviet Ethnography. Current Anthropology 33(4):371-394.

— (1998) U.S. and Russian Anthropology: Unequal Dialogue in a Time of Transition. Current Anthropology 39 (1):1-17.

Tokarev, S. A. (1968) Osnovy etnografii. Moscow: Vyshhaia shkola.

— (1978) Istoriia zarubezhnoi etnografii. Moscow: Vysshaia shkola.

Vakhtin, Nikolai and Anna Sirina (2003) Razmyshleniia posle mezhdunarodnogo seminara "Komu prinadlezhit sibirskaia etnografiia?" Etnograficheskoe Obozrenie 2003(3):141-148.

Vakhtin, Nikolai, Evgeniy Golovko, and Peter P. Schweitzer (2004) Russkie starozhily Sibiri: Sotsial'nye i simvolicheskie aspekty samosoznaniia. Moscow: Novoe izdatel'stvo. Vainshtein, Sevian (1998) Comment on V. A. Tishkov. Current Anthropology 39 (1):1213. 
Vitebsky, Piers (1992) Landscape and Self-Determination among the Eveny: The Political Environment of Siberian Reindeer Herders Today. In Bush Base: Forest Farm. Culture, Environment and Development, ed. E. Croll and D. Parkin. London: Routledge, pp. 223-246.

Wiget, Andrew, and Olga Balalaeva (2001) Khanty Communal Reindeer Sacrifice: Belief, Subsistence, and Cultural Persistence in Contemporary Siberia. Arctic Anthropology 38(1):82-99.

Ziker, John (2002) Peoples of the Tundra: Northern Siberians in the Post-Communist Transition. Prospect Heights, IL: Waveland Press.

\section{Notes}

1 'Who Owns Siberian Ethnography? An International Workshop on Methods and Approaches to Ethnography in the Russian North?’ was held 6-9 March 2002 at the Max Planck Institute for Social Anthropology, Halle, Germany, and was funded by the Max Planck Society. The workshop was organized by Patty Gray, Peter Schweitzer and Nikolai Vakhtin. This article began as a summary of key themes of the workshop written in Russian by Nikolai Vakhtin immediately after the workshop (the same summary formed the basis for a Russian language review of the workshop - see Vakhtin and Sirina 2003). This initial summary was translated into English by Patty Gray, who then substantially expanded the text. Peter Schweitzer contributed the section on the history of Siberian ethnography in the Soviet period, as well as adding generally to the text. The authors are grateful to two anonymous reviewers who read the manuscript both critically and sympathetically, and whose comments were extremely valuable in revising the text. 
The manuscript also benefited from critical readings by David Anderson, Erich Kasten, Olga Murashko, Ulrika Persson-Fischier, Florian Stammler, Aimar Ventsel, and Piers Vitebsky.

${ }^{2}$ For the purposes of this paper, 'Siberia' is used to denote the whole area of the Russian North from the Urals to the Chukotka peninsula, encompassing sub-regions that are variously referred to as the Far North, the Far East, and Siberia.

${ }^{3}$ Several Japanese scholars of Siberia could have been invited, but for purely logistical reasons were not. Thus this article is biased toward European and North American, and especially English-language, perspectives on Siberian ethnography, and perhaps unfairly neglects other perspectives. However, this workshop and the resulting article are by no means intended to exhaust the range of perspectives, and should be seen as only a first step in exploring the changes occurring in this field.

${ }^{4}$ In the case of Japan, this would have to be literally northward - and some Russian ethnographers moved reciprocally southward. Russian-Japanese collaboration in Siberia is growing (see Takakura 2003), and Japanese work in Siberia has produced significant publications (see, for example, Anderson and Ikeya 2001).

${ }^{5}$ According to Tishkov, 'The only Soviet anthropological work abroad has consisted of poorly planned and ineffectual collective expeditions to India, Vietnam, Mongolia and 
Cuba. Not one monograph based on original ethnography giving a complete picture of the life of a community has been completed in recent decades’ (Tishkov 1992:375).

${ }^{6}$ In addition, many other prominent Siberian specialists -- such as Yurii Simchenko, Anna Smoliak, Zoia Sokolova, Vladillen Tugolukov, Sev’ian Vainshtein, Vladimir Vasil'ev, and Mariia Zhornitskaia -- worked at the Moscow institute in this post-war period (and in a few cases continue to work).

${ }^{7}$ The list includes Evgeniia Alekseenko, Valentina Antropova, Vera D’iakonova, Galina Gracheva, Sergei Ivanov, Liudmila Khomich, Ekaterina Prokof'eva, Chuner Taksami, Glafira Vasilevich, and Innokentii Vdovin.

${ }^{8}$ Bromlei built his notion of 'etnos' on previous work by Shirokogorov (1922) without giving due credit. Since Shirokogorov [a.k.a. Shirokogoroff] emigrated to China after the Russian Revolution, it is not surprising that he was not much celebrated in Soviet ethnography. See also Skalník (1986).

${ }^{9}$ Caroline Humphrey’s student Philip Lineton conducted fieldwork in Siberia in the 1970s, while Terence Armstrong's student Frances Cooley conducted fieldwork in Yakutiya in the 1980s; however, neither produced a thesis. 
${ }^{10}$ Of course their conduct as researchers in no way differed from the conduct of Soviet ethnographers, but in the eyes of the authorities they were already violators simply because they were foreigners [N.V.].

${ }^{11}$ The list continues to grow, but aside from Balzer (Khanty) and Humphrey (Buriatiia), among the first to conduct field projects in Siberia were David Anderson (Zabaikal'e, Taimyr), Alexia Bloch (Evenkiia), Gail Fondahl (Buriatiia), Bruce Grant (Sakhalin), Patty Gray (Chukotka), Erich Kasten (Kamchatka; his dissertation work had been on Saami); Anna Kerttula (Chukotka), David Koester (Kamchatka; his dissertation work had been on Iceland), Yulian Konstantinov (Kola Peninsula), Petra Rethmann (Kamchatka), Debra Schindler (Chukotka), Peter Schweitzer (Chukotka), Piers Vitebsky (Yakutia; his dissertation work had been on India), Andrew Wiget (Khanty), and John Ziker (Taimyr). Nikolai Ssorin-Chaikov (Evenkiia) represents a more ambiguous case of a Russian who conducted fieldwork during his tenure as a graduate student at a North American university.

${ }^{12}$ For a list of European and North American dissertations, see Appendix II. Monographs include Anderson 2000, Bloch 2003, Bucher 2001, Fondahl 1998, Grant 1995, Gray 2004, Jordan 2003, Kerttula 2000, Rethman 2001, Ssorin-Chaikov 2003, Ziker 2002. Articles are numerous, but examples include Koester 1998; Konstantinov 2000; Schindler 1997; Schweitzer and Golovko 1995; Vitebsky 1992, Wiget and Balalaeva 2001. Edited volumes include Anderson and Ikeya 2001, Kasten 2002, 2004. It 
also bears mentioning here the works of some Russians that have been published in English, such as Golovnev and Osherenko 1999, Krupnik 1993, and Pika ed. 1999.

${ }^{13}$ The extent to which British and French traditions are emphasized in the social anthropological training of even North American students perhaps provides some explanation for the absence of Siberia in the geographical consciousness of these ethnographic traditions. Siberian ethnography was most consistently pursued in Russianlanguage, and to a lesser extent German-language social anthropology, and only in the early phases of American anthropology (and much of that was archaeology). It was represented very inconsistently in British and French social anthropology.

${ }^{14}$ Scott Polar Research Institute/University of Cambridge was one place, perhaps the only one, where post-graduate students could receive training from 'elders' who had conducted fieldwork in Siberia, i.e. Caroline Humphrey and Piers Vitebsky. Under the direction of Terence Armstrong, Scott Polar hosted long-term visits in the 1970s and 1980s by both Soviet Siberianists and Siberians, which benefited students. Ernest Gellner at Cambridge channeled many contacts among Soviet ethnographers, some of them Siberianists themselves, others like Anatoly Khazanov who, although not a Siberian specialist, facilitated the work of young Siberianists.

${ }^{15}$ It was pointed out at the workshop that, in some cases, Soviet ethnographers might have deliberately avoided contemporary issues in order to avoid having to engage with 
'vulgar Marxism', the obsession of which was the transformation of contemporary society towards socialism and ultimately communism.

${ }^{16}$ Shimkin (1990:45) supports this idea as he quotes Vdovin: 'The cadres of specialists on the ethnography of Siberian and Northern peoples are being filled with a notable lag behind contemporary scientific needs. We have a few individual persons or no specialists [at all] trained for research on the history and ethnography of a series of peoples of Samoyedic, Ugrian, Tungus and Paleoasiatic groups, as well as south Siberian Turks (Vdovin 1980:28)'.

${ }^{17}$ The issue of 'native ethnography' has a different ontological basis in Russian and Western anthropology; while in the latter it is perceived as a more recent, post-colonial development (cf. Limon 1991; Narayan 1993), in the former it was an element embedded in the project of Soviet ethnography by virtue Lenin's policy of indigenization (Balzer 1995; Slezkine 1994).

${ }^{18}$ This has occurred already in such events as the 'Jesup 2' sessions at the 1992 International Congress of Arctic Social Sciences in Quebec, the Jesup centennial conference at the American Museum of Natural History in 1997, and the revival of the British Universities Siberian Studies Seminar at Leeds in 2002. 
${ }^{19}$ The authors apologize for any omissions from this list and request to be informed of them. 